\title{
Cytotoxic Effect of Dexamethasone Restricted to Noncycling, Early G1 Phase of Melanoma Cells
}

\begin{abstract}
Abdel-Moneim M. Osman", Mansour I. Sulaiman, Zoheir A. Damanhouri
Pharmacology Department, College of Medicine, King Abdulaziz University, Jeddah, Saudi Arabia.

Email: moneimosman@hotmail.com

Received May $18^{\text {th }}, 2010$; revised May $10^{\text {th }}, 2011$; accepted May $21^{\text {st }}, 2011$.

ABSTRACT

This study deals with the inhibitory effects of dexamethsone on the proliferation of a human melanoma cells after separation into different fractions according to their position in the cell cycle using a gravity sedimentation chamber. Fractions with high percentage of G1 cells were more susceptible to the action of dexamethsone than those with a lower percentage of G1 cells. Dexamethsone stimulated the rate of incorporation of radioactive precursors into acid-precipitable materials of melanoma M-5A cells starting 24 hours after treatment for one hour. Moreover, dexamethsone treatment markedly increased the volume of the $M-5 A$ cells with increasing the possibility of stimulating the transcriptional/translational activity in the cells. This study may hopefully stimulate the development of new approaches in systemic and/or regional chemotherapy with malignant melanoma using dexamethsone with other alkylating agents to get synergestic interaction.
\end{abstract}

Keywords: Melanoma Cells, Cell Fractionation, Dexamethasone

\section{Introduction}

Although malignant melanoma has not generally been regarded a hormonally responsive neoplasm, there are some evidences suggesting that melanoma may respond to the hormonal condition of the host. Pregnancy was reported to be associated with unfavorable prognosis in stage II disease [1]. However, adrenalectomy for melanoma metastatic to the adrenal gland provides good palliation of complete regression of distant metastatic melanoma after bilateral adrenalectomy, suggesting a possible role for adrenal hormones in modifying melanoma progression in certain patients [2]. A few reports have been published about the moderate sensitivity of human as well as animal melanoma to the action of glucocorticoid steroid hormones. Bregman et al., [3] found that dexamethsone at a concentration of $1 \mathrm{uM}$ inhibited the colony formation in a human melanoma cell strain (C8146c) by 60\%. Moreover, Ramirez et al., [4], showed 85\% tumor rejection in mice challenged with B16 melanoma after administration of anti glucocorticoid-induced TNF receptor family related protein. Recently, Banciu et al., [5], reported that a glucocorticoid prednisolone phosphate encapsulated in long-circulating liposomes exerts antitumor activity through the inhibition of tumor angiogenesis. The marked if not complete reversal of the inhi- bition of cell proliferation by glucocorticoid [6] raised the question as to what the performance of the cells might be in terms of RNA, protein and melanin synthesis during their arrested or retarded proliferation. Therefore the aim of our study was directed to investigate in what phase of the cell cycle the cells would be the most sensitive to the inhibition of proliferation induced by dexamethasone.

\section{Materials and Methods}

\subsection{Cells and Cell Culture}

A human melanoma cell line M-5A was received at unknown passage level from liquid nitrogen store National Cancer Institute, Cairo University. Its characteristics have been described [7]. Cells were grown in modified minimum essential Eagle's medium to which penicillin (100 i.u./ml) and streptomycin $(100 \mathrm{ug} / \mathrm{ml})$ had been added. The medium contained $10 \%$ newborn calf serum inactivated by heating at $56^{\circ} \mathrm{C}$ for $30 \mathrm{~min}$. Cells were cultured at $3^{\circ} \mathrm{C}$ in humidified $5 \% \mathrm{CO}_{2}$ atmosphere.

\subsection{Cell Separation}

Cells were separated according to size by velocity sedimentation at unit gravity in a linear density gradient from $2 \%$ to $8 \%$ BSA on PBS. The chamber as developed by 
Tulp et al. (1980) [8] (Figure 1) contained flow deflecttors which permitted undisturbed introduction of the cushion liquid and density gradient and the undisturbed layering of the cells. The chamber was sterilized by filling it completely with 2\% formaldhyde in PBS for 24 hours. It was washed thoroughly with sterile bidistilled water followed by sterile PBS. After that the chamber was covered with aluminum foil and kept at $4^{\circ} \mathrm{C}$. The gradient mixer and other glassware were dry sterilized at $250^{\circ} \mathrm{C}$ overnight. At the time of experiment, the chamber was removed from the cold room and filled completely via inlet B with sterile cushion liquid consisting of $10 \%$ Ficoll (average molecular weight 400,000, Pharmacia, Sweden) in PBS. All solutions were introduced into the chamber from their reservoir by the force of gravity. A linear density gradient $(400 \mathrm{ml})$, prepared from two different solutions of BSA (Sigma, fraction V) in PBS (2 and $8 \%$, respectively, sterilized by ultrafilteration) was admitted to the chamber via inlet A within 25 min. by letting cushion liquid flow out via B. After that a disposable syringe was filled with $20 \mathrm{ml}$ of a cell suspension in $0.5 \%$ BSA in PBS. The plunger was removed and the syringe was connected to A by a piece of sterile silicon tubing. The cells were let to flow into the chamber within 1 min followed by an overlay of $25 \mathrm{ml}$ PBS until the meniscus of the fluid had reached the cylindrical part of the chamber. The cells were then allowed to sediment at unit gravity for about $90 \mathrm{~min}$ at $4^{\circ} \mathrm{C}$. Routinely, $50 \times 10^{6}-60$ $\times 10^{6}$ cells were thus processed. After sedimentation the content of the separation chamber were collected via A by allowing cushion liquid to flow into chamber via $\mathrm{B}$. The first $150 \mathrm{ml}$ were discarded and subsequently fractions of $10 \mathrm{ml}$ each were collected. Selected fractions were studied for DNA per cell content by flowcytomter.

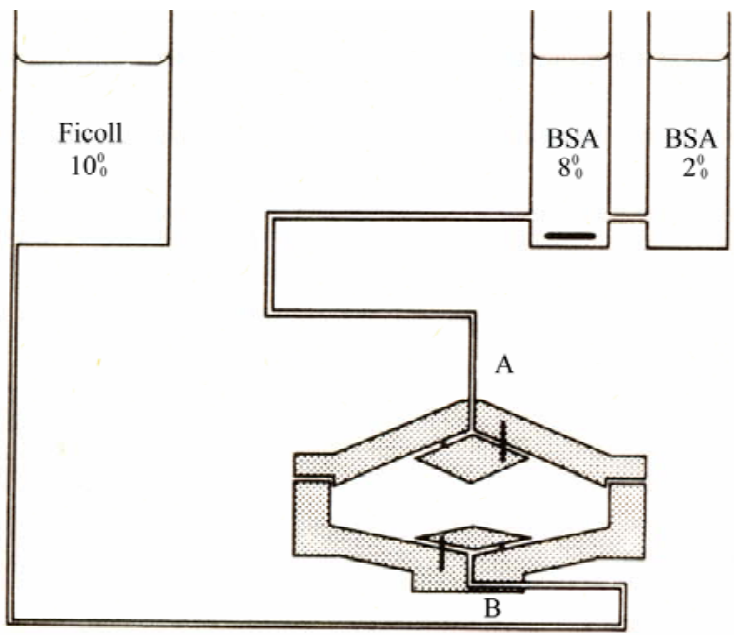

Figure 1. Schematic presentation of the system for separation of cells according to cell size in linear density gradient at unit gravity.
Moreover, their capacity for cell proliferation was determined using colony forming assay procedure described before [9].

\subsection{Determination of the Rate of $\left({ }^{3} \mathrm{H}\right)$ Uridine and $\left({ }^{14} \mathrm{C}\right)$ Leucine Incorporation}

The rate of $\left({ }^{3} \mathrm{H}\right)$ uridine and $\left({ }^{14} \mathrm{C}\right)$ leucine incorporations were determined as described before (9). $\left(6-{ }^{3} \mathrm{H}\right)$ uridine (0.1 Ci.ml, $23.4 \mathrm{Ci} / \mathrm{mmole})$ and $\mathrm{L}-\left({ }^{14} \mathrm{C}\right)$ leucine $(0.1$ $\mathrm{Ci} / \mathrm{ml}, 340 \mathrm{mCi} / \mathrm{mmole}$ ) were obtained from Amersham International, Ltd, England.

\subsection{Measurement of Cell Volume}

Cell volumes were measured using coulter counter (Model ZF) equipped with a multichannel analyzer (Tracor, TN.1705) and an XY-plotter (Tracor, TA-1148) which counts cells in a series of channels. The cell number was automatically plotted against cell size. Exponentially growing cells were inoculated into $75 \mathrm{~cm}^{2}$ Falcon flasks and 24 hours later, dexamethsone was supplied at a dose of $12.5 \mathrm{uM}$ for one hour.

\subsection{Determination of Relative Melanin Content.}

Melanin content was measured by the colorimetric method described by Whittaker [10]. Cell pellets containing $5 \times$ $10^{6}$ cells placed induplicate Beckman microfuge polyethylene tubes were suspended, lysed in $0.5 \mathrm{ml}$ of deionized $\mathrm{H}_{2} \mathrm{O}$, and subjected to 2 cycles of freezing and thawing. Perchloric acid was added to a final concentration of $0.5 \mathrm{~N}$, and the suspension was kept on ice for 10 $\mathrm{mm}$ and then centrifuged for $5 \mathrm{~mm}$ in a Beckman Model $\mathrm{B}$ microfuge. The pellets were extracted twice more with $0.5 \mathrm{~N} \mathrm{HCIO}_{4}$ followed by 2 extractions with a cold mixture of ethyl alcohol: ethyl ether (3: 1, v/v) and a final extraction with ethyl ether. The pellets were air dried, 1 $\mathrm{ml}$ of $0.85 \mathrm{~N} \mathrm{KOH}$ was added, and the pellets were dissolved by heating to $60^{\circ} \mathrm{C}$ for $10 \mathrm{~min}$. After insoluble residue was pelleted the supernatant was cooled to room temperature and the absorbance at $400 \mathrm{~nm}$ was measured in a Beckman double-beam spectrophotometer. The relative melanin content is expressed as the absorbance at $400 \mathrm{~nm}$ per $5 \times 10^{6}$ cells.

\section{Results}

\subsection{Proliferation Capacity of Separated Cells after Dexamethasone Treatment}

The initial fractions obtained from the gravity sedimentation chamber contained exclusively G1-phase cells or at least cells with diploid DNA per cell content as shown by flowcytomter (Figure 1). Subsequent fractions were enriched in S and G2/M cells, respectively. Attempts to obtain fractions containing predoniantly S and /or G2/M 


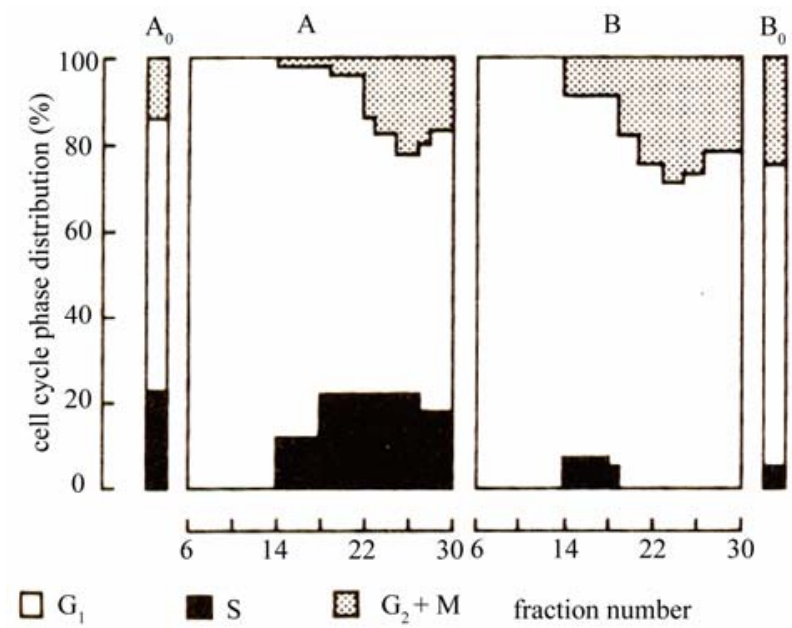

Figure 2. Cell cycle distribution of fractions of M-5A cells obtained by cell separation at unit gravity. A, untreated separated cells; $A_{0}$, untreated unseparated control; $B$, Cells treated with 12.5 uM dexamethasone for one hour and then separated; $B_{0}$, Treated unseparated control.

cells, however, remained unsuccessful. Figure 2 showed The first 5-6 fractions exhibited a very low capacity for colony formation (Table 1). However, this capacity increased sharply in the pure G1 cell fractions with increasing fraction number (149 colonies with cells exclusively with G1 compared to 35 colonies in cells with $50 \%$ G1). Moreover, there was $93 \%$ inhibition in cell proliferation after dexamethasone treatment in fraction contains $100 \%$ G1, while there was only $29 \%$ inhibition in fraction contains $50 \%$ G1.

\subsection{Incorporation of $\left({ }^{3} \mathrm{H}\right)$ Uridine and $\left({ }^{14} \mathrm{C}\right)$ Leucine by Dexamethsone Treated Cells}

Table 2 showed the effect of dexamethsone (12.5 uM) treatment on the incorporation of precursors of RNA and protein into M-5A melanoma cells. There was stimulation of $\left({ }^{3} \mathrm{H}\right)$ uridine incorporation in M-5A cells starting from 24 hours after treatment which continued till 96 hours (Table 2). $\left({ }^{14} \mathrm{C}\right.$ ) leucine incorporation was also sig-
Table 1. Effect of treatment with dexamethasone on the proliferation of melanoma $\mathrm{M}-5 \mathrm{~A}$ cells fractionated according to their position in the cell cycle.

\begin{tabular}{ccccc}
\hline \multirow{2}{*}{$\begin{array}{c}\text { Fraction } \\
\text { Number }\end{array}$} & G1 cell per & \multicolumn{2}{c}{ Colony formation per 100 cells $^{\mathrm{a}}$} \\
\cline { 3 - 5 } & Fraction & Control & Treated $^{\mathrm{b}}$ & inhibition (\%) $^{\text {ind }}$ \\
\hline 10 & $100 \pm 0$ & $149 \pm 47$ & $11 \pm 2$ & 93 \\
15 & $81 \pm 18$ & $83 \pm 26$ & $25 \pm 11$ & 70 \\
21 & $63 \pm 6$ & $88 \pm 8$ & $28 \pm 3$ & 68 \\
27 & $50 \pm 2$ & $35 \pm 5$ & $25 \pm 1$ & 29 \\
\hline
\end{tabular}

a presented are mean \pm S.E.M.

${ }^{\mathrm{b}}$ Dexamethasone, $12.5 \mathrm{uM}$ for one hour

nificantly stimulated (52 and $87 \%$ increase compared to control, 24 and 48 hours after treatment, respectively).

\subsection{Changes in Cell Volume after Treatment with Desxamethasone}

It was noticed microscopically that M-5A cells increased in size after dexamethasone treatment. Therefore, the effect of dexamethsone treatment on the cell volume was investigated in more detail in the cells the frequency distribution curve for control and treated cells obtained after 72 hours is depicted in Figure 3.

M-5A cells showed an increased frequency of largedsized cells 72 hours after dexamethsone treatment compared to control cells.

\subsection{Melanin Synthesis after Treatment with Dexamethsone.}

Table 3 showed the melanin content of M-5A cells, three days after dexamethsone treatment at a dose level of 0.25 to $12.5 \mathrm{uM}$ for $60 \mathrm{~min}$. Dexamethsone treatment showed an increase in the melanin content in M-5A cells by 14 and $153 \%$, respectively. Moreover, there was a concomitant inhibition of cell proliferation from 49 to $76 \%$ at dose level of 0.25 to $12.5 \mathrm{uM}$, respectively.

\section{Discussion}

Malignant melanoma is a relatively uncommon disease comprising $1 \%-3 \%$ of all cancers [11,12]. Melanoma has received considerable attention from both the clinical and

Table 2. Effect of dexamethasone (12.5 uM) on the rate of incorporation of $\left({ }^{3} \mathrm{H}\right)$ uridine and $\left({ }^{14} \mathrm{C}\right)$ leucine in human melanoma cells.

\begin{tabular}{|c|c|c|c|c|c|c|}
\hline \multirow{2}{*}{$\begin{array}{l}\text { Time after } \\
\text { treatment } \\
\text { (hr) }\end{array}$} & \multicolumn{3}{|c|}{$\begin{array}{l}\text { Rate of }\left({ }^{3} \mathrm{H}\right) \text { uridine incorpora incorporation } \\
\text { incorporation } \\
\left(\mathrm{dpm} / 0.25 \times 10^{6} \text { cells } / 60 \mathrm{~min}\right) \times 10^{-3}\end{array}$} & \multicolumn{3}{|c|}{$\begin{array}{l}\text { Rate of }\left({ }^{14} \mathrm{C}\right) \text { leucine incorporation } \\
\left(\mathrm{dpm} / 0.25 \times 10^{6} \text { cells } / 60 \mathrm{~min}\right) \times 10^{-3}\end{array}$} \\
\hline & Control & Treated & $\mathrm{T} / \mathrm{C} \times 100$ & Control & Treated & $\mathrm{T} / \mathrm{C} \times 100$ \\
\hline 24 & $3.7 \pm 0.14$ & $6.3 \pm 0.07(3)$ & 170 & $0.35 \pm 0.05$ & $0.53 \pm 0.03(6)$ & $152^{\mathrm{b}}$ \\
\hline 48 & $4.18 \pm 0.57$ & $7.20 \pm 0.76$ (8) & $173^{\mathrm{c}}$ & $0.60 \pm 0.06$ & $0.13 \pm 0.04(6)$ & $187^{\mathrm{z}}$ \\
\hline 72 & $4.52 \pm 0.49$ & $9.39 \pm 1.14$ (3) & $208^{\mathrm{c}}$ & $0.38 \pm 0.03$ & $0.70 \pm 0.04$ (8) & $185^{\mathrm{a}}$ \\
\hline 96 & $3.93 \pm 0.21$ & $8.62 \pm 1.07(3)$ & $219^{c}$ & $0.50 \pm 0.10$ & $0.91 \pm 0.08$ & $182^{\mathrm{d}}$ \\
\hline
\end{tabular}

Cells were treated for one hour with $12.5 \mathrm{uM}$ dexamethsone, 48 hours after treatment, $\left({ }^{3} \mathrm{H}\right)$ uridine and $\left({ }^{14} \mathrm{C}\right)$ leucine were added for 60 min. Cell numbers were counted in a hemocytomter and acid-precipitatable radioactivity was determined as described in the materials and methods. Presented are means \pm S.E.M. Number of observation are in parenthesis, $p$-value for the differences between control and treated samples were ${ }^{\mathrm{a}}<0.001$; $^{\mathrm{b}}<0.002$; ${ }^{\mathrm{c}}<0.02 ;{ }^{\mathrm{d}}<0.05$; other differences were not significant. 


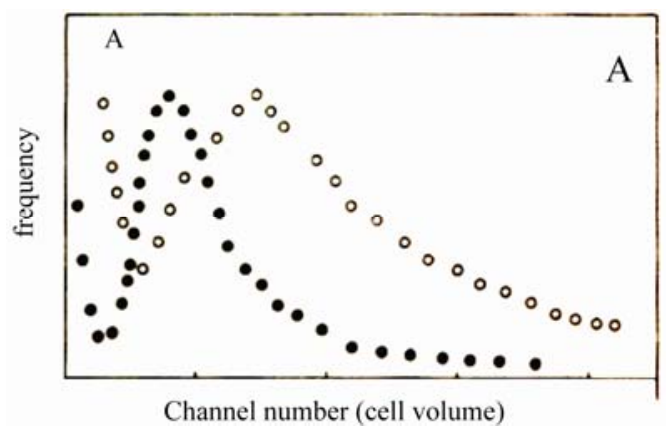

Figure 3. Volume of melanoma M-5A cells after treatment with dexamethasone in comparison with untreated controls. Cells were treated with dexamethsone $12.5 \mathrm{uM}$ for one hour, cell volume were analyzed 72 hours after treatment. Chart redrawn after the coulter counter plots. A, M-5A cells; • Control; ${ }^{\circ}$ Treated.

Table 3. Concentration dependence of the effect of dexamethasone on the cell proliferation and melanin content of M-5A cell ${ }^{\mathbf{a}}$.

\begin{tabular}{ccc}
\hline Dose (uM) & Relative cell number $(\%)^{\mathrm{b}}$ & $\begin{array}{c}\text { Relative melanin } \\
\left.\text { content }^{(\%)}\right)^{\mathrm{b}}\end{array}$ \\
\hline 0 & 100 & 100 \\
0.25 & 51 & 114 \\
0.625 & 30 & 197 \\
1.25 & 25 & 213 \\
12.5 & 24 & 253 \\
\hline
\end{tabular}

${ }^{\mathrm{a}}$ Dexamethsone was supplied for one hour, 72 hours before the measurement of cell number and melanin content. ${ }^{\mathrm{b}}$ Mean of two experiment in duplicate.

investigational point of view due to marked tendency to disseminate and many patients die as result of distant metastases [13,14]. Glucocorticoid (triamcinolone) has shown an inhibitory effect on melanoma B16/F10 cell growth [15]. Moreover, Osman et al. [9] showed inhibittory effect of dexamethsone on the proliferation of melanoma M-5A cells by arresting the cells in G1 phase. So this study was directed to gain better insight the sensitivity of cell cycle phases of M-5A cells to the action of dexamethsone. Dexamethsone showed much inhibitory effect on G1 phase of M-5A cells, these results indirectly agreed with that reported by Ramos et al. [16] who demonstrated that the steroid-induced expression of $\mathrm{C} / \mathrm{EBP}$ alpha that is necessary to mediate the glucocorticoid G1 cell cycle arrest of rat hepatoma cells and implicates a role for this transcription factor in the growth control of liver-derived epithelial tumor cells. In addition, the changes in expressions of regulators of cell cycle (p27 (kip1) and cyclin D2) and/or apoptosis (Bak and Bcl-XL) by anti-inflammatory drugs like dexamethasone may contribute to proliferation suppression and apoptosis in human oestoblasts (hOBs) [17]. It seems likely that a cellular response to dexamethsone will in principle be highly selective. During the dexamethsone-induced arrest [9], the cells approximately doubled in size as deter- mined by coulter counter analysis (Figure 3). This result was not unexpected, because large, nonproliferating cells persisted in the arrested culture as was seen microscopically. These observations suggested a more generalized increase in the synthesis of protein and RNA which have been shown in our study in which there was an increase in both uridine and leucine incorporation (Table 2). Moreover, there was an increase in the melanin content of M-5A cells after dexamethsone treatment which was parallel to inhibitory effect seen on the proliferation of the M-5A cells. This result indirectly agreed with that reported by Koo et al., [18], where they found that in vivo treatment of human melanoma xenograft tumors in athymic nude mice with anthrax lethal toxin (LeTx) resuled in a significant or complete tumor regression without apparent side effects, suggesting that inhibiting the MAPK (mitogen-activated protein kinase) signaling pathway may be a useful strategy for treating melanoma. Additionally, interrupting MAPK signaling with LeTx in both melanoma cells and melanocytes lead to dramatic melanin production, perhaps explaining the inhibitory effect of dexamethsone on the proliferation of $\mathrm{M}-\% \mathrm{~A}$ cells which could be due to increase the melanin pig.

\section{Acknowledgements}

The authors are most grateful to King Fahd Medical Center, Jeddah, Saudi Arabia for offering research facilities and technicians for technical assistance.

\section{REFERENCES}

[1] M. H. Shiu, D. Schottenfeld, B. Maclean and J. G. Fortner, "Adverse Effect of Pregnancy on Melanoma: A Reappraisal,” Cancer, Vol. 37, No. 1, 1976, pp. 181-187.

[2] F. J. Collinson, T. K. Lam, W. M. Bruijn, J. H. M. De Wilt, M. Lamont. J. K. Thompson and R. F. Kefford, "Longterm Survival and Occasional Regression of Distat Melanoma M, Etastases after Adrenal Metastectomy,” Annals of Surgical Oncology, Vol. 15, No. 6, 2008, pp. 1741-1749. doi:10.1245/s10434-008-9836-y

[3] M. D. Bregman, E. Peters, D. Sander, F. L. Meyskens Jr., Dexamethsone, "Prostaglandin A and Retinoic Acid Modulation of Murine and Human Melanoma Cells Grown in Soft Agar," Journal of the National Cancer Institute, Vol. 71, No. 5, 1983, pp. 927-932.

[4] M. T. Ramirez, A. Chow, D. Hirschhorn Cymerman, T. H. Terwey, A. A. Hochma, S. Lu, R. C. Miles, S. Sakaguchi, A. N. Houghton and M. R. van den Brink, "Glucocorticopid-Induced TNF Receptor Family Related Gene Activation Overcomes Tolerance/Ignorance to Melanoma Differentiation Antigens and Enhances Antitumor Immunity,” The Journal of Immunology, Vol. 176, No. 11, 2006, pp. 6434-6442.

[5] M. Banci, J. M. Metselaar, R. M. Schiffelers and G. Storm, "Antitumor Activity of Liposomal Prednisolone Phosphate Depends on the Presence of Functional Tu- 
mor-Associated Macrophages in Tumor Tissue,” Neoplasia, Vol. 10, No. 2, 2008, pp. 108-117.

doi:10.1593/neo.07913

[6] L. A. Smets, B. Bout and M. Brouwer, “A Tulp Cytotoxic Effect of Dexamethsone Restricted to Noncycling, Early G1 Phase Cells of L1210 Leukemia,” Journal of Cellular Physiology, Vol. 116, No. 3, 1983, pp. 397-403. doi:10.1002/jcp.1041160318

[7] K. Liao, P. B. Dent and P. B. McCulloch, "Characterization of Human Malignant Melanoma Cell Lines. I. Morphology and Growth Characteristics in Culture,” Journal of the National Cancer Institute, Vol. 54, No. 5, 1975, pp. 1037-1044.

[8] A. Tulp, J. G. Collard, A. A. M. Hart and J. A. Aten, “A New Unit Gravity Sedimentation Chamber,” Analytical Biochemistry, Vol. 105, No. 1, 1980, pp. 246-256. doi:10.1016/0003-2697(80)90452-2

[9] A. M. Osman, O. A. Nasseir and N. R. Ismail, "Potential Mechanism for the Effects of Dexamethasone on Growth of Human Melanoma Cells in Vitro,” Health, Vol. 2, No. 8, 2010, pp. 857-886. doi:10.4236/health.2010.28129

[10] J. R. Whittak, "Changes in Melanogenesis during the Dedifferentiation of Chick Retinal Pigment Cells in Cell Cultures,” Developmental Biology, Vol. 8, No. 1, 1963, pp. 99-127. doi:10.1016/0012-1606(63)90028-9

[11] W. H. McCarthy, A. L. Black and G. W. Milton, "Melanoma in New South Wales: An Epidemiologic Survey, 1970-1976,” Cancer, Vol. 46, No. 2, 1980, pp. 427-432. doi:10.1002/1097-0142(19800715)46:2<427::AID-CNCR 2820460237>3.0.CO;2-E

[12] L. Nathanson, "Epidemiologic and Etiologic Considerations in Malignant Melanoma,” In: J. J. Costanzi, Ed.,
Cancer Treatment and Research, Martinus Nijhoff, the Huige, Vol. 9, 1983, pp. 1-27. doi:10.1146/annurev.genet.38.072902.092717

[13] R. L. Comis, "DTIC (NSC-45388) in Malignant Melanoma: A Perspective,” Cancer Treat Rep, Vol. 60, No. 2, 1976, pp. 165-176.

[14] J. J. Costanzi, "The Chemotherapy of Malignant Melanoma,” In: J. J. Costanzi, Ed., Cancer Treatment and Research, Martinus Nijhoff, the Huige, Vol. 9, 1983, pp. 259-274.

[15] A. Ristic-Fira, M. Vujcic, M. Krstic-Demonacos, D. Kanazir, "Identification and Characterization of Glucocorticoid Receptors in B16 Mouse Melanoma Cells," Endocrine Regulations, Vol. 33, No. 3, 1999, pp. 109-115.

[16] R. A. Ramos,Y. Nishio, A. C. Maiyar, K. E. Simon ,C. C. Ridder, Y. Ge and G. L. Firestone, "Glucocorticoid- Stimulated CCAAT/Enhancer-Binding Protein Alpha Expression is Required for Steroid-Induced G1 Cell Cycle Arrest of Minimal-Deviation Rat Hepatoma Cells," Molecular and Cellular Biology, Vol. 16, No. 10, October 1996, pp. 5288-5301.

[17] J. K. Chang, C. J. Li , H. J. Liao , C. K. Wang, G. J. Wang and M. L. Ho, "Anti-Inflammatory Drugs Suppress Proliferation and Induce Apoptosis through Altering Expressions of Cell Cycle Regulators and Pro-Apoptotic Factors in Cultured Human Osteoblasts,” Toxicology, Vol. 258, No. 2-3, 28 April 2009, pp. 148-156.

[18] Han-M., Koo, M. VanBrocklin, M. J. McWilliams, S. H. Leppla, N. S. Duesbery and G. F. Vande Woude, “Apoptosis and Melanogenesis in Human Melanoma Cells Induced by Anthrax Lethal Factor Inactivation of Mitogen-Activated Protein Kinase,” PNAS, Vol. 99, No. 5, 2002, pp. 3052-3057. doi:10.1073/pnas.052707699 